\title{
Sources of the Incumbency (Dis)Advantage
}

\author{
George Avelino Filho ${ }^{1}$ \\ https://orcid.org/0000-0001-8281-0194 \\ Ciro Biderman ${ }^{1}$ \\ https://orcid.org/0000-0002-5451-0220 \\ Scott Desposato ${ }^{2}$ \\ https://orcid.org/0000-0001-7722-1766
}
${ }^{1}$ Fundação Getúlio Vargas. Escola de Administração de Empresas de São Paulo. São Paulo/SP, Brazil

2University of California San Diego. La Jolla, CA, United States

An emerging literature finds that legislators frequently suffer a negative incumbency advantage in developing countries but disagrees as to the sources of this anti-incumbent bias. We contribute to this literature by examining the case of Brazil, where the extant literature predicts a large incumbency disadvantage. Building a new methodology for OLPR which leverages both inter- and intraparty thresholds, we find, contrary to expectations, a large 'positive' incumbency advantage. We further exploit within-country variation and show that this advantage appears to be largest in the least developed areas. Our results suggest that previous work may be confounding country-specific factors with development levels.

Keywords: Electoral systems; electoral strategies; incumbency advantage; regression discontinuity Design; Brazil.

http://doi.org/10.1590/1981-3821202200010003

For data replication, see: https://doi.org/10.7910/DVN/5GVHTE

Correspondence: George Avelino Filho. E-mail: george.avelino@fgv.br

Acknowledgments: The authors gratefully acknowledge the support of FAPESP (project \# 2013/15658-1) and the excellent research assistance from Mauricio Y. Izumi and Henrique A. C. F. Hott.

This publication is registered under a CC-BY Licence. 
R esearch on the comparative incumbency advantage finds a great deal of cross-national variation. In the United States, where the literature originated, a positive incumbency advantage is a widespread and enduring regularity, with incumbents receiving a significant electoral bonus due to their office-holding. Nevertheless, in other countries, scholars have found a diversity of incumbency effects, including cases with a positive incumbency advantage, no advantage, and even a sizable disadvantage. It is unclear, however, why some countries have positive and others negative incumbency advantages, with scholars offering a variety of tentative hypotheses from single case studies.

We make three contributions by examining the incumbency advantage in the Brazilian Chamber of Deputies. First, we contribute to methods for studying open-list proportional representation (OLPR) systems. Scholars studying OLPR systems generally focus on intraparty competition to measure incumbency effects but ignore interparty competition. We offer a new methodology that allows for the simultaneous study of inter- and intraparty thresholds, and we use that approach herein.

Second, we exploit Brazil's great internal diversity to test the three most prominent comparative theories regarding the factors affecting the incumbency advantage: development, party strength, and intraparty competition. For the first, we compare the incumbency advantage across districts with different levels of development. Regional differences in Brazil are stark, with some states' indicators comparable to Sub-Saharan Africa, and others to parts of Europe. Brazil also includes both highly disciplined and inchoate political parties, allowing us to examine the relationship between party strength and the incumbency advantage. Lastly, electoral districts vary greatly in the number of legislators they elect, allowing us to explore the association between district magnitude and the incumbency advantage. Although these tests do not identify causal effects, they offer important suggestive evidence for future research.

Third, we seek to increase understanding of the Brazilian case. The Brazilian Congress is an important and under-studied case in the literature on incumbency effects. While several scholars have examined the incumbency

$$
\text { (2022) } 16(1) \quad \text { - e0004-2/39 }
$$


advantage in Brazilian mayoral elections, much less attention has been paid to Congressional elections, perhaps because of the complexities of the OLPR electoral system, with the important exceptions of Hidalgo and Oliveira (2016), and Meireles (2020).

We first estimate the causal effect of incumbency on political careers in the Brazilian Chamber of Deputies. Contrary to current predictions, we find a substantial and consistent 'positive' impact of incumbency on some political careers in Brazil. In further analysis, and contrary to expectations, we show that only part of the incumbency advantage is due to incumbents' additional access to campaign resources. Finally, leveraging within-country variance, we show that contrary to the conventional wisdom, the incumbency advantage is 'largest' in the 'least' developed areas of Brazil. We also find evidence that district magnitude is correlated with the incumbency advantage. We also find modest support for the extant literature's hypotheses regarding party strength.

\section{The comparative incumbency advantage}

The incumbency advantage is a concern in all candidate-centered electoral systems. An advantage potentially threatens system responsiveness to voters, as it implies that elected officials may leverage public resources to increase their electoral prospects (COX and KATZ, 1996). Scholars attribute this advantage to a number of factors. Many of these are particular to the US institutional and party configurations, though some could potentially be generalized to other legislatures. Key variables include features of the US' single-member district electoral system, including the extension of one-person-one-vote to Congress and subsequent redistricting engineering (COX and KATZ, 2002; DESPOSATO and PETROCIK, 2003); personal vote advantages of incumbents (developed through franking, constituency service, media attention, and pork-barreling); voters' use of incumbency as a signal of candidate quality (FOWLER, 2018); strategic candidate emergence with the deterrence of quality challengers (JACOBSON and KERNELL, 1981); and simple random selection (ZALLER, 1998).

However, a growing literature shows that far from being a paradigmatic case, the US' incumbency advantage is an exceptional outlier globally. Scholars have 
examined the incumbency advantage in many countries and have found broadly divergent patterns. In most cases, the incumbency advantage is much smaller than in the US. Indeed, in many countries, there is a 'negative' incumbency advantage whereby incumbents receive, on average, fewer votes than challengers and are less likely to win than challengers. These results have appeared in diverse settings with very different electoral environments, providing opportunities for theory development. Core findings from this literature are reported in Table 01.

Table 01. Comparative incumbency advantage

\begin{tabular}{|c|c|c|c|}
\hline Country & Institution & $\begin{array}{l}\text { Incumbency } \\
\text { Advantage }\end{array}$ & Citation \\
\hline Brazil & National & + & $\begin{array}{l}\text { Hidalgo and Oliveira (2016) } \\
\text { Meireles (2020) }\end{array}$ \\
\hline Canada & National & + & Ariga, 2010 \\
\hline Canada & $\begin{array}{l}\text { National } \\
\text { National and }\end{array}$ & + & Kendall and Rekkas. 2012 \\
\hline Chile & Local & + & Shiumerini, n.d. \\
\hline Colombia & National & - & Klasnja and Titiunik, 2017 \\
\hline Denmark & National & + & Dahlgaard, 2016 \\
\hline Finland & National & + & Ariga, 2010 \\
\hline India & National & - & Linden, 2004 \\
\hline Italy & National & + & Ariga, 2010 \\
\hline Italy & National & $0 /+$ & Golden and Picci, 2016 \\
\hline Ireland & National & + & Redmond and Regan, 2015 \\
\hline Japan & National & $-/-/+$ & Ariga, 2010 \\
\hline Japan & National & - & Ariga, 2015 \\
\hline UK & National & + & Ariga, 2010 \\
\hline Zambia & $\begin{array}{l}\text { National and } \\
\text { Local }\end{array}$ & - & MacDonald, 2014 \\
\hline
\end{tabular}

Source: Elaborated by the authors.

Note: Each entry reports a country-study result. Institutions may be national or local, legislative or executive offices. The incumbency advantage is reported as positive $(+)$, negative $(-)$, or as not being statistically significant $(0)$. In papers with more than one core analysis, multiple results are reported.

One empirical pattern has drawn particular attention: less developed countries tend to have negative incumbency advantages (Colombia, India, and Zambia), while more developed countries frequently have positive incumbency advantages (Canada, Denmark, Finland, Italy, UK, and USA); there are important exceptions, such as Chile and Japan.

$$
\text { (2022) } 16(1) \quad \text { - } 00004-4 / 39
$$


This general trend has been widely noted in the extant literature. For example, MacDonald writes “...an emerging body of research has also demonstrated strong incumbency dis-advantages in Brazil, ... India ..., and a range of other lowand middle-income countries" (MAcDONALD 2014, p. 01). From Lee: "studies of developing democracies, however, have found evidence that incumbency may hurt reelection chances of legislators and local officials" (LEE, 2016, p. 01). Roh notes that "recent studies of incumbency effects in developing countries have found that incumbents are less likely to win than challengers in the next election after they have served a term" (ROH, 2017, p. 112). Likewise, Lucardi and Rosas, argue that "evidence from Brazil, India, Rumania or Zambia suggests that holding elected office can be the kiss of death for politicians and parties in developing countries" (LUCARDI and ROSAS, 2016, p. 66). Other scholars pointing to this trend include Ariga et al. (2016) and Uppal (2009).

Scholars have offered several hypotheses to explain patterns of incumbency advantage or disadvantage. Some have focused on institutions, especially single- and multimember districts. Examining Japan, Ariga (2015) finds null and negative incumbency advantages and suggests that intraparty competition and multimember districts facilitate voters' shifting away from incumbents to similar competitors. Scholars writing on Italy have shown that proportional representation and multimember districts can empower parties to reward loyalty and restrict personal vote-seeking, thus reducing or eliminating the incumbency advantage (GOLDEN and PICCI, 2015) ${ }^{1}$. Lucardi and Rosas (2016) offer a creative coordination explanation, where voters update voting strategies based on past election results.

Other scholars have focused on underdevelopment as the cause of a negative incumbency advantage, examining a variety of mechanisms through which incumbency may reduce vote share and chances of election in the future. One such mechanism is that voters reject incumbents due to misuse of public resources, especially in developing countries (KLAŠNJA, 2015). Another relies on legislative resources and professionalization. Eggers and Spirling (2017) note that

${ }^{1}$ For a broad survey of the comparative literature on the incumbency advantage, see MacDonald (2014).

$$
\text { (2022) } 16(1) \quad \text { e0004-5/39 }
$$


in legislatures in the developing world, limited staff, weaker committees, and fewer position-taking opportunities reduce incumbents' ability to build a personal vote, which should also reduce incumbents' advantage. A third possibility is examined by Uppal (2009), who ties the advantage to performance, finding that increased public goods provision reduces incumbents' disadvantage in India.

These creative hypotheses, however, seem to be ad-hoc and inconsistent with the literatures on clientelism, voting behavior, and the personal vote. Indeed, we would expect the incumbency advantage to be greatest in the least developed areas. Our logic relies on two preconditions: the opportunity for voters to punish or reward individual politicians via preference voting and the ability of politicians to develop a personal vote through increased publicity, campaign resources, or by delivering policy, pork, or constituency service to voters. In relation to the first, for incumbents to enjoy an advantage, the political system must have a degree of personalism, and the electoral institutions (formal and informal) must give politicians considerable latitude for making choices (JACOBSON, 2015). If there are no electoral institutions allowing voters to reward or punish individual politicians, most sources of the incumbency advantage are eliminated ${ }^{2}$.

In addition, office-holding must provide politicians with some ability to cultivate the personal vote. Presumably, incumbency provides access to a variety of resources that can be used to increase future vote share (SCHIUMERINI, 2018). Incumbents may have greater media access, name recognition, and general visibility through special provisions such as franking privileges in the United States, which allow legislators to send mail without paying postage. Incumbents may also steer public works or other projects to their electoral base, creating jobs and public infrastructure. Such activities could help build popular support, either directly, as voters observe and approve of public improvements, or indirectly, by raising more campaign contributions from local contractors. In some systems, incumbents can appoint a sizeable staff of activists to support legislative activity and constituency

${ }^{2}$ Of course, one could study the partisan incumbency advantage, as several authors do. One could also examine whether political parties steer more (or less) opportunities to incumbents than to challengers.

$$
\text { (2022) } 16(1) \quad \text { - } \quad 0004-6 / 39
$$


service. This staff, indebted to the representative, also act as loyal activists who are mobilized as campaign workers. In some cases, legislators have control over the distribution of public goods, such as school enrollment, driver's licenses, or private goods, such as bicycles, food, or other benefits. These resources can be most effectively deployed to build an incumbency advantage when they are directly controlled by individual legislators. When controlled by party organizations or broader coalitions, the direct benefits in terms of incumbency advantage should be much smaller.

A key implication is that all else equal, the incumbency advantage should be largest in the least developed and poorest contexts, where the marginal utility to voters of the benefits that a politician may deliver are greatest. In such contexts, voters are especially dependent on politicians for the distribution of basic goods and services. Incumbents typically enjoy much greater access to such goods than do challengers. Incumbents can intercede for constituents with government agencies, they can make sure a constituent gets a scarce public hospital bed, they may even distribute meals and food to needy constituents. In some countries, legislators have special discretionary funds they can distribute for social programs. Meanwhile, challengers generally have little to offer except promises of action and policies which remain abstract and distant from the concrete problems of voters in impoverished settings.

This logic makes the trends observed in the literature especially surprising. We would expect that in the least developed contexts, especially when incumbents have some control over public resources, they would use these resources to build political support and maintain campaign machines. Consequently, the incumbency advantage should be largest in the least-developed areas. Yet, cross-national empirical work finds the opposite - there is an incumbency disadvantage in many developing contexts.

One possible explanation for the apparent relationship between development and the incumbency advantage is that it reflects some other factors specific to each context. The political systems represented in Table 01 vary widely in electoral rules, degree of individual politicians' autonomy and personalism, and 
political culture. Any one of these factors might confound the relationship between development and incumbency effects that is observed cross-nationally. In helping to clarify these issues, our analysis will use a within-case test to examine the correlation between development and incumbency effects, holding most other variables constant.

\section{The Brazilian system}

By examining the Brazilian case, we expect to contribute to the literature on incumbency effects in three ways. First, Brazil meets some of the criteria described as causing a negative incumbency advantage, and previous work has found a negative advantage in mayoral elections. Yet, limited attention has been given to legislative elections. Second, we offer a new approach for examining the incumbency advantage in OLPR systems. Previous work on such systems in Italy and other cases uses regression discontinuity to explore intraparty list thresholds but has overlooked interparty electoral thresholds. We will test for both inter- and intraparty thresholds in this paper. Finally, we leverage the diverse electoral contexts in Brazil to explore three prominent explanations for the incumbency (dis)advantage: development, party discipline, and intraparty competition.

We begin by reviewing the Brazilian political system and the features expected to promote or attenuate an incumbency advantage. Features of Brazil's electoral system match the extant literature's profile of a country with a negative incumbency advantage. Brazil is a developing country with an OLPR system, which promotes intraparty competition and facilitates intraparty vote transfers ${ }^{3}$. Corruption scandals in Congress have been frequent and massive. Finally, participation rates in Brazil are relatively high. Each of these features has been linked to weaker or negative incumbency advantages.

With respect to legislative politics, a key finding in the literature is that politicians hold progressive ambition - they frequently leave Congress to run for offices at the local level or to take positions in local bureaucracies (SAMUELS, 2003).

\footnotetext{
${ }^{3}$ Among others, see Ames (2001, 1995a and 1995b), and Mainwaring (1999, 1995, and 1991).
}

$$
\text { (2022) } 16(1) \quad \text { - } \quad 0004-8 / 39
$$


This phenomenon is partially attributed to the difficulties of winning reelection 4 . Incumbency effects are often attributed to the personal vote, yet evidence suggests that incumbents have fairly limited name recognition ${ }^{5}$.

However, other characteristics that serve as a counterweight to these incumbency-weakening features may strengthen incumbents. The weak partisanship and preference ballot system of this personalistic system should support an incumbency advantage (JACOBSON, 2015). In addition, all 513 Brazilian deputies are supported by a staff of up to twenty-five assistants and can direct significant public resources to pet projects and constituencies in their districts ${ }^{6}$. Incumbents should at least have much more visibility, media access, and public presence than non-office holders. Finally, incumbency may work as a signal of candidate quality for voters (FOWLER, 2018). Our analysis will contribute to clarify these relationships.

Brazil's large and diverse democracy also provides an opportunity to test for several hypotheses about incumbency advantage within the country, specifically the broad relationship between development and the incumbency advantage, as well as the role of party strength and district magnitude. Brazilian states serve as electoral districts and vary dramatically in development indicators. The poorest states have profiles similar to sub-Saharan Africa, while the most developed states are comparable to some European countries. At the same time, the entire country uses the same electoral system, has the same electoral calendar, shares the same broader political culture and general historical context, and is framed by the same national politics. We will thus test whether incumbency advantage varies with the development level of candidates' constituencies.

\footnotetext{
${ }^{4}$ Other scholars, however, have suggested that the progressive nature of ambition may have been overstated, as many legislators do run for reelection (PEREIRA and RENNÓ, 2013).

${ }^{5}$ For instance, the ESEB data (Estudo Eleitoral Brasileiro/Brazil Electoral Survey) for the 2014 elections show that $36.1 \%$ of voters did not recall the name of their candidate about a month after the elections. (<http://www.cesop.unicamp.br/cesop/csp_databases/view/3716> Question Q5CDA). This 'electoral amnesia' tends to increase between elections. According to Almeida (2006), just before the 2006 elections, the share of voters that did not recall their candidate in the 2002 elections had increased to almost 75\%.

${ }^{6}$ See: <https://www2.camara.leg.br/transparencia/acesso-a-informacao/copy_of_perguntasfrequentes/deputados\#verbas>.
}

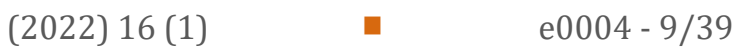


A second hypothesis in the literature that we will test involves the relationship between party strength and the incumbency advantage (GOLDEN and PICCI, 2015). With respect to party strength, the Brazilian party system is generally described as weak, but some exceptions can be exploited for testing. Some parties, most notably the Worker's Party (or PT), maintain control over nominations, enforce discipline on their members, and have followers who display attitudes and behaviors typical of dedicated partisans (GUARNIERI, 2011; KECK, 1992; SAMUELS AND ZUCCO JR., 2018). Finally, a third hypothesis in the literature is that the incumbency advantage is affected by the degree of intraparty competition due to substitution effects (ARIGA, 2015). Intraparty competition varies with district magnitude (CAREY and SHUGART, 1995), so we test for the impact of district magnitude on the incumbency advantage - Brazilian district magnitude ranges from 8 to 70 seats. We will leverage these differences in development, party strength, and district magnitude to provide within-country tests of their impact on the incumbency advantage.

\section{Data and empirical strategy}

Our data was collected from the 'voto seção' files maintained by the Superior Electoral Court (TSE). Previous work uses published datasets extracted from TSE's website. Since the 'voto seção' files are published before the TSE rules on candidates' appeals, they directly reflect the candidates' electoral performance rather than their performance in post-election litigation. This raw data from the TSE, although public, is not properly organized - double lines of information, missing identification codes, lack of links across different data sets, and distinct data formats and codes across elections are common problems that may generate inconsistencies and even loss of data. To avoid such problems, we extracted all electoral data from the well-organized CepespData (cepespdata.io) ${ }^{7}$. Finally, we included educational data from the Census carried out by the IBGE

\footnotetext{
${ }^{7}$ More specifically, we used the CepespData API (<https://github.com/Cepesp-Fgv/cepesp-r>) to extract the data.
}

$$
\text { (2022) } 16(1) \quad \text { a } \quad \text { a } 0004-10 / 39
$$


(Brazilian Institute of Geography and Statistics). All codes used to build the dataset and to analyze it are available in the Supplemental Materials ${ }^{8}$.

We define the incumbency advantage as the increase (or decrease) in the probability of reelection due to tenure in office. Measurement of this advantage is difficult primarily due to selection bias, as candidates often choose not to run when the odds are against them. Strong incumbents deter challengers, and weak incumbents often retire. The effect of each of these factors is to inflate estimates of the incumbency advantage. Recently, scholars have employed regression discontinuity designs (RDD) to estimate the causal impact of incumbency on electoral outcomes (LEE, 2008). RDD designs based on elections are particularly common since the discontinuous assignment of victory in close races often provides a credible research design to make causal inferences about the effect of incumbency on the likelihood of reelection. When elections are very close, candidates' assignment to the winner or loser can be treated as-if random, and the causal impact of holding office can be measured.

This framework is elegant and simple when used in two-candidate, singlemember district elections, but there are challenges when using it in more complicated electoral systems. In particular, Brazil's OLPR system, with many parties and candidates, creates many potential thresholds or discontinuities, including both intra- and interparty lists. Brazil's OLPR is well-discussed in the literature, and we refer the interested reader to that literature ${ }^{9}$. We present the basics of the system to illustrate the many possible thresholds for analysis.

Table 02 shows a hypothetical election result under Brazil's OLPR system, with four parties, 100 voters, four seats, and 19 candidates. Voters cast a single vote either for an individual candidate or for the entire party list. Seats are allocated to parties based on the total votes received by the party (combining votes cast for candidates and party list). After the distribution of seats among parties, seats are allocated to individual candidates based on the number of votes they

\footnotetext{
${ }^{8}$ All supplementary material is available at the Harvard Dataverse repository (https://doi.org/10.7910/DVN/5GVHTE).

${ }^{9}$ Among others, see Ames (2001, 1995a and 1995b), and Mainwaring (1999, 1995, and 1991).
}

(2022) $16(1)$

e0004-11/39 
received in the party list. For example, Party $\mathrm{Z}$ secured two seats based on its total of 37 votes, allocated to the top-two vote-getters in the party, Cesar and Marta. Party $\mathrm{X}$ secured one seat, which went to Miriam, the top vote-getter in that party.

This system provides two types of thresholds - intra- and interparty. The intraparty thresholds involve competition between candidates within the party list. The most straightforward and obvious threshold is the gap between the last winning candidate and the first losing candidate within each party list. For example, in Party Z, Marta with five votes was elected narrowly over Nelson with four votes, naturally defining a threshold for comparison. This intraparty threshold can also be extended to more than just the last winner and first loser, as others might be close to the intraparty threshold. In Party X, Angelica was also competitive - just one vote behind João and two behind Miriam. A slight change in vote share could have resulted in any one of them winning or losing.

Table 02. Hypothetical election results under OLPR

\begin{tabular}{ccccccccc}
\hline & \multicolumn{2}{c}{ Party W } & \multicolumn{2}{c}{ Party X } & \multicolumn{2}{c}{ Party Y } & \multicolumn{2}{c}{ Party Z } \\
\cline { 2 - 8 } Rank & Cand & Votes & Cand & Votes & Cand & Votes & Cand & Votes \\
\hline 01 & Lara & 03 & Miriam & 06 & Ruy & 11 & Cesar & 23 \\
02 & Rosa & 02 & João & 05 & Antonio & 08 & Marta & 05 \\
03 & Júlia & 01 & Angelica & 04 & Jorge & 07 & Nelson & 04 \\
04 & Alice & 01 & Darcy & 03 & Udson & 02 & Ze & 03 \\
05 & & & Carlos & 01 & Patricia & 0 & Walter & 02 \\
List & Party W & 0 & Party X & 01 & Party Y & 08 & Party Z & 0 \\
Total & & 07 & & 20 & & 36 & & 37 \\
Seats & & 0 & & 01 & & 01 & & 02 \\
\hline
\end{tabular}

Source: Elaborated by the authors.

Note: Parameters: 04 parties, 04 seats, 19 candidates, and 100 voters.

Second, there is an 'interparty' threshold, which determines the number of seats each party receives. Consider Antonio in Party Y. He was not elected, and he was 03 votes behind Ruy, the last (and only) winner in his party. However, to be elected, Antonio does not need to surpass Ruy. Instead, with just one more vote, Antonio's party would earn another seat. Since Antonio is the secondplace candidate in Party Y, he would receive that seat. In this case, the intraparty threshold is $03+01$ votes to beat Ruy, but the interparty threshold is just 01 vote. 
Empirically, many losing or winning candidates are in fact closer to interparty thresholds than to intraparty thresholds, but existing work completely ignores these between-party thresholds. There are two negative consequences of ignoring interparty thresholds: first, doing so treats some candidates as farther from the threshold than they are. Second, candidates from losing parties are entirely discarded from interparty analysis. For example, the candidates in Party W in our hypothetical example would all be discarded by an analysis based on intraparty thresholds approaches. Yet, candidates from such parties may be 'close' to being elected via interparty thresholds.

A number of authors have examined incumbency effects in list systems, but with important differences from our work. For example, Folke (2014) uses interparty discontinuities to test the impact of small parties on policy, but he does not examine intraparty discontinuities, incumbency effects, or impacts on individual legislators' careers. Ade, Freier, and Odenhdahl (2014) examine the German mixed system to see how incumbency effects vary depending on the party in control of the government, but they limited their analysis to the 'direct district' candidates. Micozzi and Lucardi (2019), in a clever paper, adapt RDD to closed-list proportional representation to study the impact of incumbency on careers and progressive ambition in a party-centric system. Fiva and Smith (2018) examine the incumbency advantage in Norway's proportional representation system, although their focus is on the formation of family dynasties. All these works, however, examine closed-list proportional representation systems in which interparty thresholds are the only relevant thresholds - because intraparty list order is generally determined by the party leadership.

In an open-list context, the only existing analysis of interparty thresholds that we are aware of is the work of Kotakorpi, Poutvaara, and Terviö (2017). They analyze incumbency effects in Finland's OLPR system. Their analysis uses a bootstrap method in which vote shares are resampled from a multinomial distribution. This approach might be appropriate for a case like Finland, where districts are relatively small (only one has a population over $1,000,000$ ) and where parties are relatively consolidated. However, in Brazil, where districts are massive both in geography and population, and where legislative 
voting decisions are not made until voters reach polling places and often draw on cues from social networks, the multinomial distribution's strong assumption of independence could severely understate proximity to thresholds.

Our approach combines the inter - and intraparty thresholds. Our running variable is the number of votes needed for candidate $i$ to change her electoral status. We examine both intra- and interparty electoral thresholds and use the smaller distance. Specifically, we use the minimum number of additional votes that a nonelected or losing candidate would have to earn to be a winning candidate, or the minimum number of votes that an elected candidate would have to lose to be a nonelected candidate. For candidate $i$ in list $j$, our running variable is:

$$
R_{i, j}=\frac{\left(V_{i, j}-\tau_{i, j}\right)}{\left(V_{i, j}+V_{L, j}\right)}
$$

where $R_{i, j}$ is the running variable for candidate $i$ on list $j, V_{i, j}$ is the number of votes received by candidate $i, j, \tau_{i, j}$ is the threshold for candidate $i, j$ 's electoral status to change (from elected to unelected, or from 'unelected' to elected), and $V_{L, j}$ is the number of votes received by the First Loser in list $j$ : the candidate on list $j$ who lost and had more votes than any other candidate in list $j$ who lost. For example, in Table 02, the first losers are Lara, João, Antônio, and Nelson for parties W, X, Y, and Z, respectively.

The critical variable here is $\tau, i, j$, the threshold to change candidate $i$ 's electoral status. For a losing candidate, this is the minimum number of votes he would need to have received in order to be elected:

$$
\tau_{i, j}=\min \left(\tau_{i, j, \text { Intra }}, \tau_{i, j, \text { Inter }}\right)
$$

where $\tau_{j, j, j}$, Inter is the number of votes $i, j$ would have needed to win by 01 . earning another seat for the party and 02 . being in a position to receive that seat, and $\tau, i, j$, Intra is the number of votes $i$ would have needed to win by surpassing the last winning 
candidate in list $j^{10}$. For example, for candidate Antonio in Party Y in Table 02 , the interparty threshold is 02 - Antonio could win by increasing his votes by 02 , which would earn the party another seat, which he would receive. For the same candidate, the intraparty threshold is 04 - to win without earning another seat, he would have to earn 04 votes, which would put him in first place in the party list, above the last (and only) winner in Party Y, Ruy.

For a winning candidate, $\tau_{i, j}$ is the threshold for losing - the largest number of votes that she could have received but still lost the election, all other results unchanged:

$$
\tau_{i, j}=\max \left(\tau_{i, j, \text { Inter }}, \tau_{i, j, \text { Intra }}\right)
$$

This could occur in either of two ways. First, candidate $i$ could have received so few votes that she was below candidate $V_{L, 1, j}$, the first loser. Then the First Loser would be elected, and candidate $i$ would not be elected. This could also occur in the case that list $j$ receives one (or more) fewer seats as a result of candidate $V_{i, j}$ receiving fewer votes. This could also occur in the case that list $j$ receives one (or more) fewer seats as a result of candidate $V_{i, j}$ receiving fewer votes, and one of these lost seats would have been candidate $i$ 's. Consider candidate Marta in party Z in Table 02 . Her intraparty threshold was 03 - with this number of votes she would be below Nelson on the party list. Her interparty threshold was also 03 - had she received just three fewer votes, the party would have lost a seat - hers!

Rather than using raw votes needed to win or lose a seat, we normalize our running variable. Parties, districts, and candidates vary greatly in their capacity to earn or lose votes. A celebrity candidate in São Paulo might earn an extra 1,000 votes for simply telling the right joke during an interview. In contrast, a newcomer to politics in the state of Amapá might have to travel by boat for days to reach isolated voters and earn an additional 100 votes. These variations in electoral environments and campaign capacity contrast with the paradigmatic case of US

\footnotetext{
${ }^{10}$ Generally, to win a seat via an interparty threshold, a candidate would need to surpass the first loser and also earn another seat for the party. Obviously, there is no intraparty threshold for candidates from a party that earned no seats. In that case, the only relevant threshold is the intraparty threshold.
} 
Congressional elections where districts are required, as nearly as possible, to have equal population. Because of this diversity across Brazil, we normalize our running variable using the average of candidate i's votes and the first loser's vote (the votes received by the strongest losing candidate in a party): $\left(V_{i, j}+V_{L, j}\right)$. Note that using $V_{L, j}$, the votes of the first loser, allows us to include in our analysis parties that did not win any seats.

Our normalization also addresses an important feature of OLPR: candidates across parties may face different thresholds. Some deputies might be elected with as few as $0,1 \%$ of the votes or might lose while receiving as much as $10 \%$ of the votes. This is different from elections with only two candidates in which the victory cutoff is always 50\%. For those cases, Cattaneo et al. (2016) propose an alternative that allows the estimation of heterogeneous effects by cutoff. In this paper we were not concerned with heterogeneity by cutoffs, so we did not explore this opportunity. We opt to use the 'normalizing-and-pooling approach' that provides a synthetic result 11 .

Of course, there are many other ways to normalize distance to thresholds, reflecting different perspectives on what 'close' means in these contexts. In addition, there are many other possible dependent variables. The broad findings do not change regardless of which approach we use, although the magnitude of estimates and p-values naturally fluctuate ${ }^{12}$.

\footnotetext{
${ }^{11}$ This means that the results presented "can be interpreted as a double average: the weighted average across cutoffs of the local average treatment effects for all units facing each particular cutoff value (...) [giving] higher weights to those values of the cutoff that are most likely to occur and include more observations" (CATTANEO et al., 2016, p. 1230). The authors, however, do not propose a unique indicator for the impact using weights different from the 'normalizing-andpooling approach'.

${ }^{12}$ In defining the running variable, Boas and Hidalgo (2011) and Golden and Picci (2015) use the raw vote differences to identify candidates close to the threshold. As the number of votes varies across states, the first choice would artificially increase observations from the smallest ones. Boas and Hidalgo (2011) also consider standardizing by using the total votes as the denominator but refrain, as we did, as this choice would artificially increase the number of close elections from the largest districts. A third alternative would be to use the total party votes as the denominator, as suggested by Meireles (2020); however, votes for party lists are still a too large denominator, also inflating the number of close elections. Although our decision for a more restricted definition of the running variable plays against our intents, it produces more comparable results across Brazilian states.
}

$$
\text { (2022) } 16(1) \quad \text { - e0004-16/39 }
$$


Table 03 compares the frequency of different threshold types for all candidates and for $20 \%$ bandwidth candidates. When examining all candidates, $42.57 \%$ are closer to intraparty thresholds than to interparty thresholds. Existing approaches using intraparty analysis thus drop almost $60 \%$ of all candidates. Even when examining a $20 \%$ bandwidth, about $19.51 \%$ of candidates are closer to interparty than intraparty thresholds, suggesting that previous work excludes or mismeasures the running variable for up to $20 \%$ of candidates.

Two additional challenges derive from the problem of self-selection of candidates into future elections. First, while some candidates from time $t$ both winners and losers - run again in time $t+1$, others do not. Estimates of the incumbency advantage are thus likely to be biased when we examine only the outcomes for candidates who run again in $t+1$, and they may be biased in either direction. For example, losers who are generally weaker candidates may choose not to run again. Their choice might lead analysts to underestimate the incumbency advantage. At the same time, it might be that weaker winners choose not to run again, so that our estimates of the incumbency advantage would be biased upward. There are several other possibilities, making it difficult to interpret simple differences in vote share between winners and losers who run again in future elections.

Table 03. Frequency of threshold types

\begin{tabular}{cccc} 
& Intraparty Threshold & Interparty Threshold & \multirow{2}{*}{ Closer } \\
\cline { 2 - 4 } Closer & 10023 & 13521 & \multirow{2}{*}{ All Observations } \\
\cline { 2 - 4 } Within 20\% & $(42.57 \%)$ & $(57.43 \%)$ & 2344 \\
Threshold & 1066 & 258 & \multirow{2}{*}{1324} \\
\hline
\end{tabular}

Source: Elaborated by the authors based on CEPESP (2020).

Note: Due to rounding, figures add to more than $100 \%$.

We address this problem by following Magalhães' (2015) strategy: we focus on the unconditional incumbency advantage - the probability that a candidate from time $t$ runs and wins at time $t+1$. Effectively, this includes candidates who did not run at time $t+1$ in the analysis. In the Supplemental Materials, we compare our findings with the conditional incumbency advantage, examining only winners and 
losers who ran again. Our own observations of Brazilian politics over many years suggest that this approach is in fact more conservative than the unconditional incumbency advantage, although we cannot observe all selection mechanisms and the risk of bias mentioned above. Results examining the conditional incumbency advantage are similar to those presented herein.

The second challenge is that losing candidates from parties that win seats automatically become substitutes or 'suplentes'. They may temporarily (in some cases, permanently) substitute for election winners in the legislature. For example, an elected candidate might be sworn in and, within a few weeks, leave to serve in the cabinet of a state government. In these cases, 'suplentes' are called, according to the votes they received, to fill the vacant legislative positions. If the original officeholder returns to Congress, the 'suplente' then must give up the seat. Usually, at most 131 'suplentes' pass through Congress during a term ${ }^{13}$. The amount of time spent in the Chamber, however, is not entirely exogenous: a governor might dismiss a deputy serving as Secretary of Transportation because the deputy's 'suplente' in the legislature has not been reliable. Because of the potential endogeneity in the assignment of 'time in legislature', we exclude this threshold from our analysis and define as incumbents only the 513 candidates elected in time $t^{14}$.

We estimate variations of the following equation:

$$
\begin{gathered}
y_{i, p, s, t+4}=\propto+\rho E_{i, p, s, t}+\delta_{1} M_{i, p, s, t}+\delta_{2} M_{i, p, s, t}^{2}+\cdots+\delta_{p} M_{i, p, s, t}^{p}+\lambda_{p}^{p}+\lambda_{s}^{s}+\lambda_{t}^{t}+ \\
\beta_{1} x_{1, i, p, s, t}+\beta_{2} x_{2, i, p, s, t}+\cdots+\beta_{k} x_{k, i, p, s, t}+\varepsilon_{i, p, s, t}
\end{gathered}
$$

Where $y_{i, p, s, t+4}$ is the outcome of interest in $t+4, E_{i, p, s, t}=1\left[v_{i, p, s, t} \geq v_{j *, p, s, t}\right]$, i.e., is an indicator (dummy) variable coded 01 if the candidate was elected and 0 if she was not elected. The impact of incumbency is measured by $\rho$. The $\lambda$ variables

13The exact numbers are 131, 113, 117, 145, 107 for the five completed legislatures between 1999 and 2019. We thank the Banco de Dados Legislativos do Cebrap for this information.

${ }^{14}$ In other words, our treatment is being elected at the time ' $t$ '. We consider the higher possibility of taking over either a state or a federal cabinet position as part of the incumbency advantage.

$$
\text { (2022) } 16(1) \quad \text { e0004-18/39 }
$$


represent fixed effects for party, district, and time, the $x$ 's are covariates relevant for the estimation, ${ }^{15}$ and $\varepsilon_{i, p, s, t}$ is a spherical error term with the usual characteristics. Following the standards in the literature (see LEE, 2008), we explore several polynomial orders, all employing the optimal bandwidth, suggested by Imbens and Kalyanaraman (2012), and developed by Calonico et al. (2017, 2014a, 2014 b), and Cattaneo et al. (2019) in their 'rdrobust' package. We have also run a local linear regression to estimate the incumbency effect.

\section{Descriptive statistics}

We analyze elections for federal deputy for six elections $(1998,2002,2006$, 2010, 2014, and 2018). Since we analyze the effect of incumbency on subsequent elections, the first year of data (1998) will be used just for independent variables; all dependent variables will be associated with elections starting in 2002.

Table 04 shows descriptive statistics for the main variables. Winners running in $t+4$ received on average almost 15 times the number of challengers' votes. Similarly, almost $50 \%$ of incumbents were reelected in subsequent elections, while just $0.8 \%$ of challengers were elected. The third entry shows that incumbents are more likely to run again than those that lost a previous election: $70.3 \%$ of winners ran in the next election, versus $12.9 \%$ of losers. For incumbents that ran again in $t+4$, the likelihood of winning a seat is $70.2 \%$, while for challengers competing again, it was just $6.4 \%$.

Combining the likelihood of both running again and winning conditional on running again gives the unconditional likelihood of winning a seat in $t+4$. For incumbents, this is 0.49 . The two required steps to be reelected (running again and winning given that the candidate ran again) have similar rates for incumbents (about 70\%). These figures are quite different for challengers. The likelihood of running again (12.9\%) is twice that of winning the next election conditional on running again $(6.4 \%)$.

\footnotetext{
${ }^{15}$ We considered age, age squared, a dummy variable indicating if the candidate is male, a dummy variable indicating if the candidate is married, and a dummy variable indicating if the candidate has completed college or not.
} 
Table 04. Descriptive statistics for the main variables for Challengers and Incumbents

\begin{tabular}{lllll}
\hline Variable & Candidate & Obs. & Average & St. Dev \\
\hline \multirow{2}{*}{ Votes $_{t}$} & Challengers & 20,979 & 6,727 & 13,620 \\
& Incumbents & 2,565 & 100,491 & 80,722 \\
\multirow{2}{*}{ Elected } & & 20,979 & $0,8 \%$ & $9,1 \%$ \\
\multirow{2}{*}{ Run $_{t+4}$} & Challengers & 2,565 & $49,4 \%$ & $50,0 \%$ \\
& Incumbents & 20,979 & $12,9 \%$ & $33,6 \%$ \\
Elected $_{t+4} \mid \operatorname{Run}_{t+4}$ & Challengers & 2,565 & $70,4 \%$ & $45,6 \%$ \\
& Incumbents & 2,699 & $6,4 \%$ & $24,5 \%$ \\
& Incumbents & 1,807 & $70,2 \%$ & $45,8 \%$
\end{tabular}

Source: Elaborated by the authors based on CEPESP (2020).

Note: Due to rounding, the multiplication may not yield the number in the table. For instance, the precise percentage of losers that ran again (line 05) is 0.1286525 , which multiplied by the 20979 losers, results in the 2699 losers that run again.

\section{Results}

Figures $1 \mathrm{~A}, \mathrm{~B}$, and $\mathrm{C}$ show the discontinuity in the full sample 'break' point for the likelihood of running again, the likelihood of being elected, and the number of votes. In the case of the likelihood of running again or winning the subsequent election, the lower bound on the right side is well above the upper bound on the left side of the Figure. The graph suggests a large incumbency advantage of about $20 \%$ in reelection seeking (1B) and 30\% in winning reelection (1A).

Figure $1 \mathrm{C}$ shows the same relationship for the logarithm of votes in the subsequent election, conditional on candidates running again. This result is not directly comparable to other results from Figure 01 because it only includes candidates who ran again four years later, which likely leads to mismeasurement. We expect that the weakest losers are those least likely to run again, which suggests that our measure is biased downward ${ }^{16}$. Even so, we find weak evidence of an incumbency advantage in terms of votes.

\footnotetext{
${ }^{16} \mathrm{One}$ might also argue that the impact of incumbency on votes is biased upward if the strongest incumbents move on and run for higher office. This may be the case, but it represents a very small number of candidates, while the number of losers that fail to run again is quite high.
}

$$
\text { (2022) } 16(1) \quad \text { e0004-20/39 }
$$


Figure 01. Discontinuity in the number of votes (2002 to 2018)

\section{A. Likelihood of reelection}

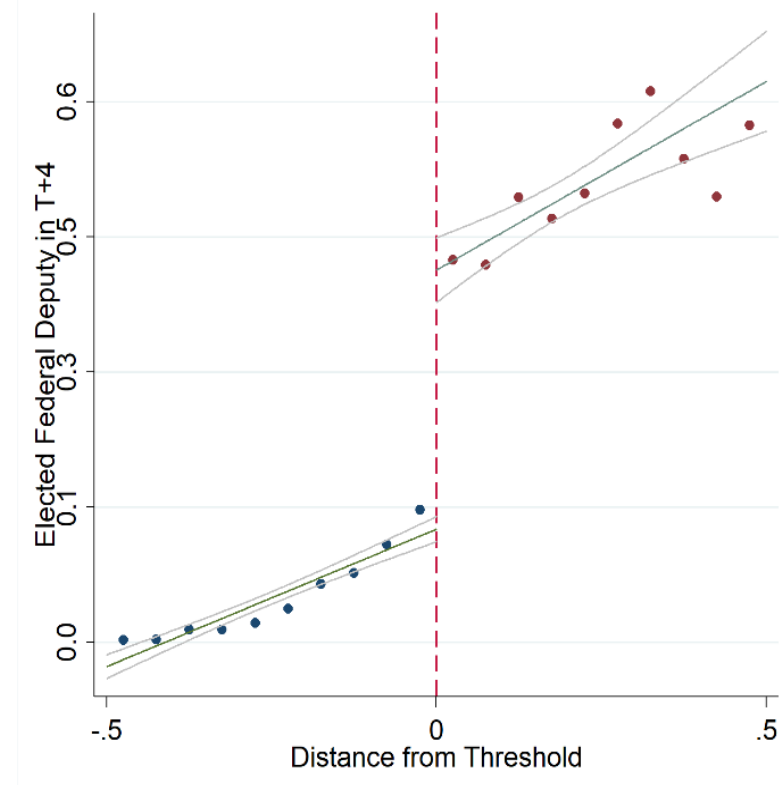

C. $\log ($ Votes $)$ in $t+4$

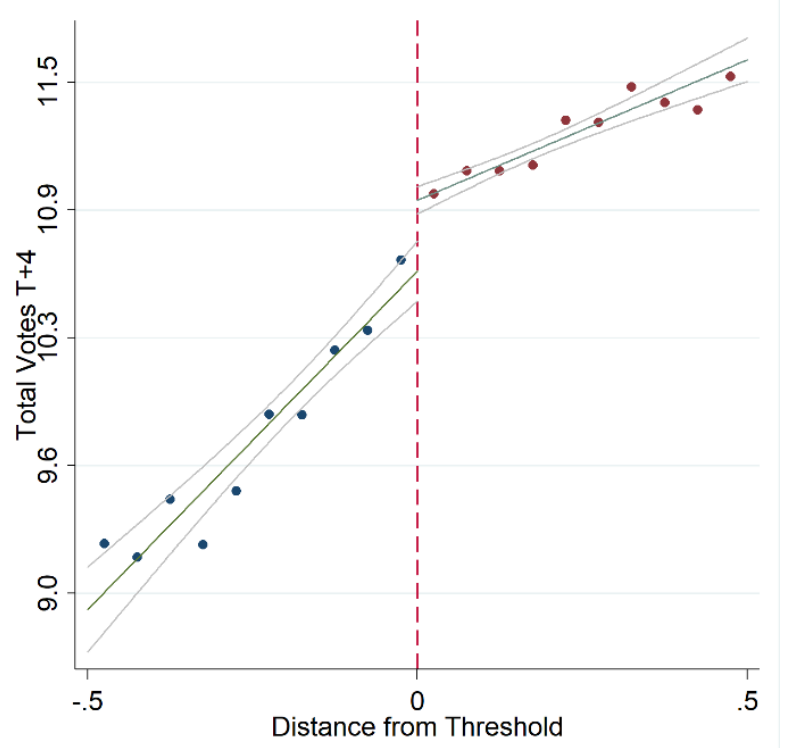

\section{B. Likelihood of running again}

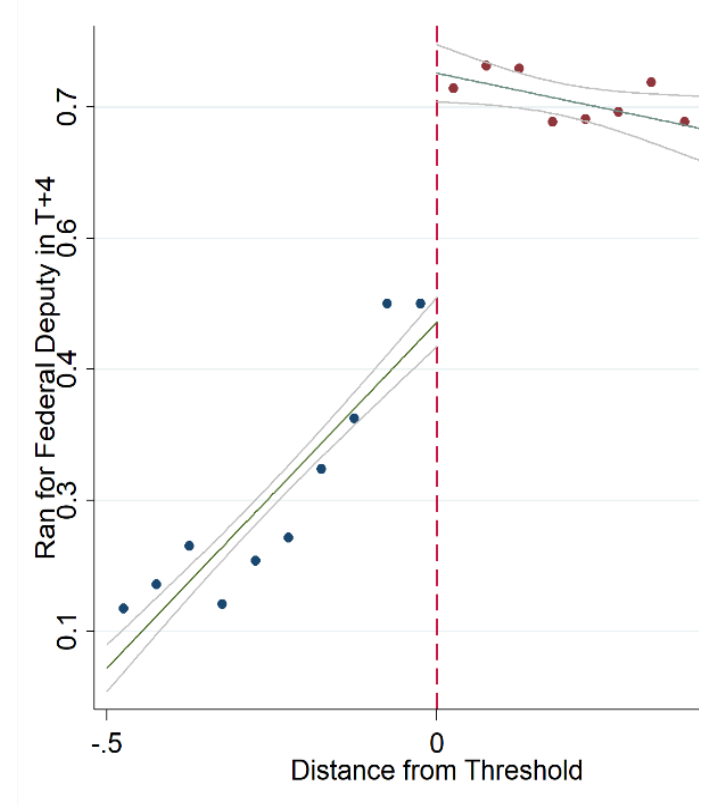

Source: Elaborated by the authors based on CEPESP (2020).

Note: Regression line (in green) and confidence intervals (in grey) are calculated using robust standard errors for $95 \%$ confidence level. 
Table 05. Balance test for selected variables (2002-2018, 20\% Bandwidth)

\begin{tabular}{cccccccc}
\hline Variables & Losers & obs & Winners & obs & $\begin{array}{c}\text { Optimal } \\
\text { Bandwidth }\end{array}$ & $\begin{array}{c}\text { RD } \\
\text { Estimator }\end{array}$ & P-value \\
\hline Votes (t) & 49,627 & 738 & 67,321 & 852 & 11,9 & 3295 & 0,547 \\
Candidate age & 50.4 & 1,227 & 51.2 & 1385 & 19,1 & $-0,4$ & 0,663 \\
$\quad$ College & $85 \%$ & 761 & $87 \%$ & 874 & 12,3 & $-5 \%$ & 0,107 \\
Married & $72 \%$ & 1,198 & $75 \%$ & 1346 & 18,7 & $1 \%$ & 0,886 \\
$\quad$ Genre & $89 \%$ & 1,107 & $93 \%$ & 1274 & 17,3 & $1 \%$ & 0,82 \\
$\begin{array}{c}\text { Mean wage UF } \\
\text { Literacy UF }\end{array}$ & $1,950.91$ & 1,543 & $1,905.64$ & 1633 & 23,9 & $-70,08$ & 0,738 \\
$\begin{array}{c}\text { Log(Population) } \\
\text { UF }\end{array}$ & 86.1 & 1,482 & $85.4 \%$ & 1588 & 22,9 & $-0,7$ & 0,756 \\
$\begin{array}{c}\text { Gini Index UF } \\
\text { \% elderly }\end{array}$ & 15.9 & 1,852 & 15.9 & 1898 & 29 & 0,0 & 0,949 \\
population UF \\
$\quad \%$ young
\end{tabular}

Source: Elaborated by the authors based on CEPESP (2020).

Note: Table reports RDD regressions for each of the exogenous variables as dependent variable using optimal bandwidth and local linear estimation

Table 05 shows that incumbents and challengers are balanced using optimal bandwidth. We estimated a local linear RDD for each of the dependent variables showing that the variables are indeed balanced; the lowest p-value is 0.107 for the proportion of candidates with a college degree, but the second-lowest is 0,547 , showing that we would not reject the null hypothesis that the coefficients are the same for any reasonable confidence level. As expected, the use of a more restricted bandwidth results in higher p-values given that the sample size is reduced.

Figure 02 shows our core result: a strong - over 20\% - positive incumbency advantage in Brazil ${ }^{17}$. An incumbent is also more likely to run again than a very similar challenger ${ }^{18}$. Both the coefficient and the statistical significance are robust to different polynomial orders. The (conditional) incumbency effect on votes is positive; however, it is imprecisely estimated, as is expected when considering the estimation for the full sample on Figure 01.

\footnotetext{
${ }^{17}$ As mentioned earlier, all results use the 'rdrobust' package. We omit the coefficients of covariates and show just our variables of interest. Full results are in the supplemental materials.

${ }^{18}$ Notice that we have just the candidates that run at least in two subsequent elections, reducing the mple from more than 18,000 to around 4,000 observations.
}

$$
\text { (2022) } 16(1) \quad \text { a } \quad \text { e0004-22/39 }
$$


Figure 02. Incumbency effect for federal deputies in Brazil for different polynomial specifications (1998 to 2018)

Incumbency effect on the likehood of reelection

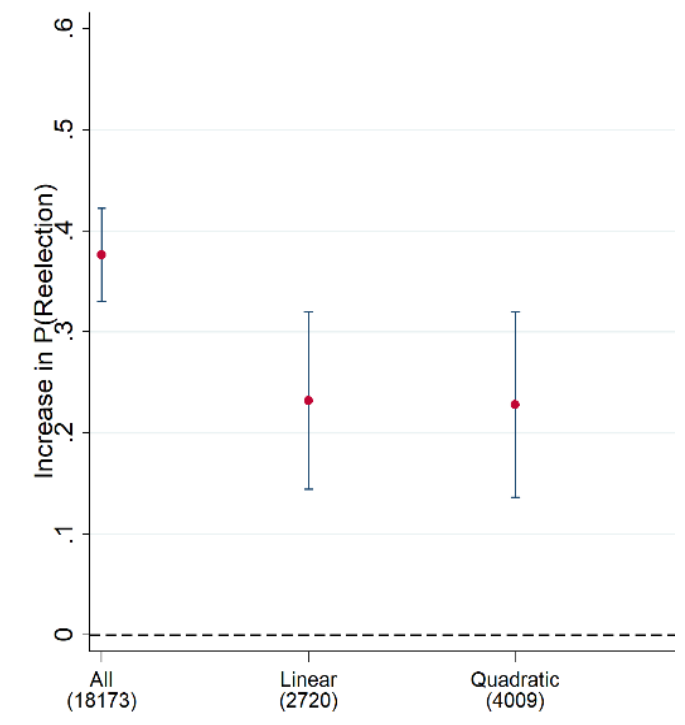

Incumbency effect on the likehood of running again

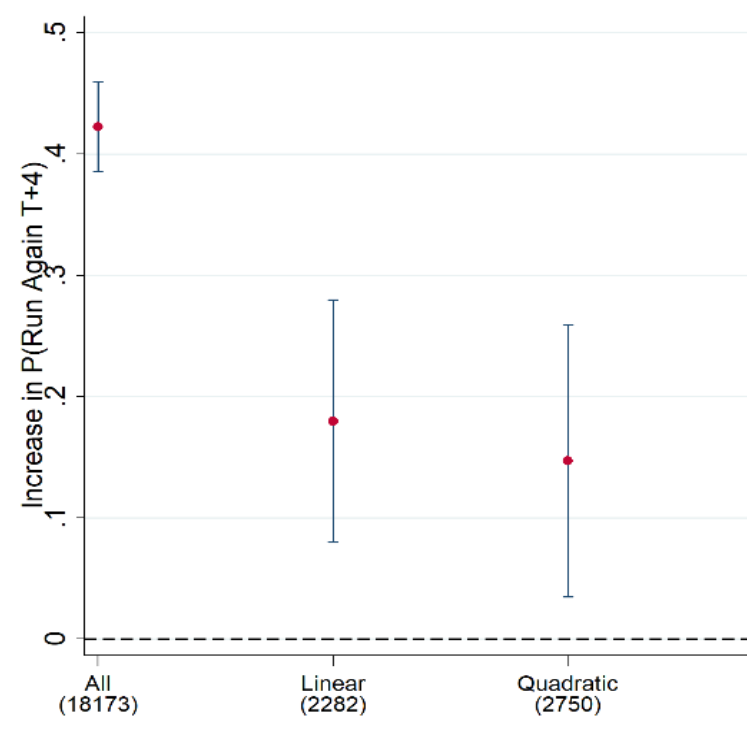

Incumbency effect on the $\log$ (Votes) in $t+4$

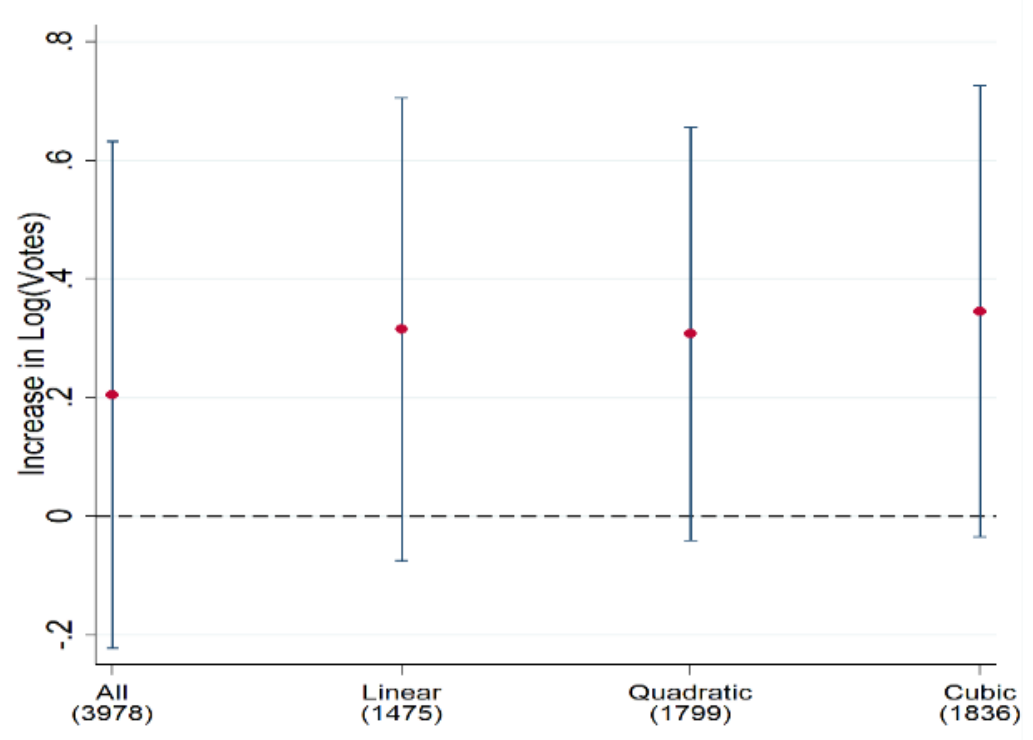

Source: Elaborated by the authors based on CEPESP (2020).

Notes: 01. Binning estimator (red dots) and confidence intervals (black line) are calculated using robust standard errors and $95 \%$ confidence level. 02 . The number of observations in parenthesis is defined by optimal bandwidth following Imbens and Kalyanaraman (2012). 
An incumbent is almost $20 \%$ more likely to run again than a competitive challenger. As shown in Table 03, in the case of incumbents, both the likelihood of running again and the likelihood of winning conditional on running again is about $70 \%$. As for challengers, using a $20 \%$ difference for both events, we found that the likelihood of running again is 50\% and of winning conditional on running again is $28 \%$. Based on these figures, the unconditional likelihood of competitive challengers winning the next election is $14 \%$, about one-third of the reelection rate of incumbents. Finally, the (conditional) effects of incumbency on votes, although positive in all specifications, are not significant in any model specification.

Our first finding is that Brazilian legislators enjoy a sizeable positive incumbency advantage. Winning an election not only raises the chances of reelection, but it possibly increases the incumbent's vote share. Although it is not easy to be reelected to Congress in Brazil, holding a seat in the federal legislature seems to provide significant support for legislators in their reelection bids.

\section{Incumbency and progressive ambition}

One limitation of our results is that there may be selection effects in the decision to run again. If the strongest challengers move on and run for other offices, our estimates might be biased upward; if the strongest incumbents do so, then our estimates might be biased downward. This may seem an odd possibility in other countries, but scholars have argued that Brazilian political careers are characterized by 'progressive ambition', with legislators moving between national and local politics in a non-linear pattern of career progression (SAMUELS, 2003).

Consequently, we now examine incumbency and career paths. Figure 03 compares the career paths of candidates after two or four years since their bid for the Chamber of Deputies, examining whether they ran for higher office (Senate, Governor, or President), or lower office (state deputy, mayor, or city council). 
Figure 03. Incumbency effect on future office-seeking for federal deputies in Brazil for different polynomial specifications (1998 to 2018)

A. Incumbent effect on running for higher position in the following election

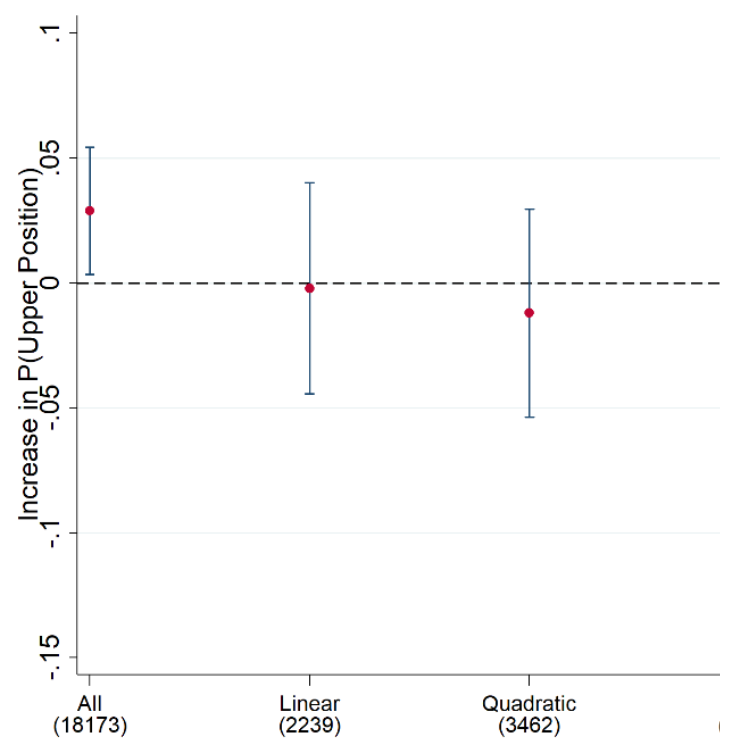

B. Incumbent effect on running for lower position in the following election

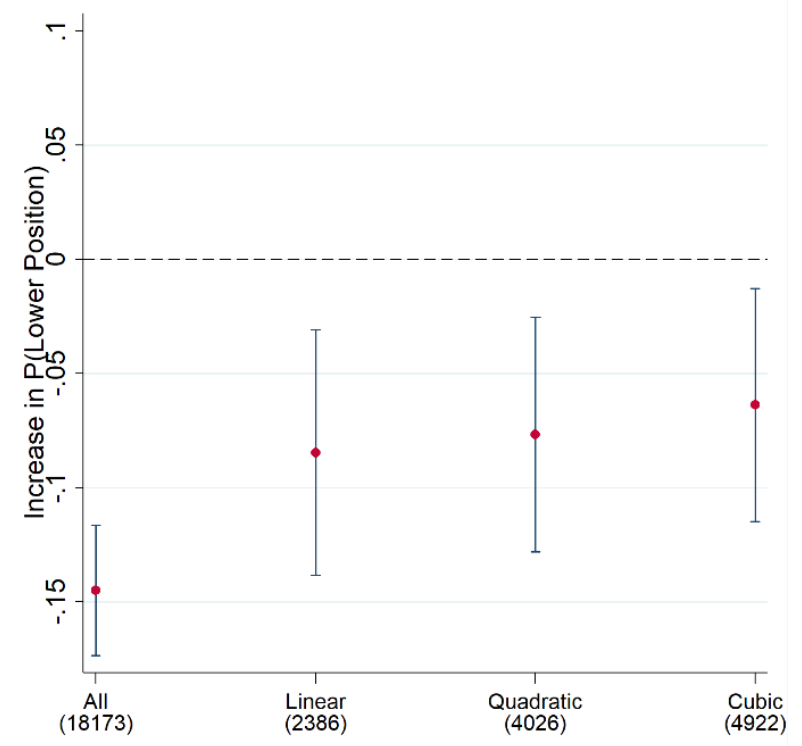

Source: Elaborated by the authors based on CEPESP (2020).

Notes: 01. Binning estimator (red dots) and confidence intervals (black line) are calculated using robust standard errors and $95 \%$ confidence level. 02 . The number of observations in parenthesis is defined by optimal bandwidth following Imbens and Kalyanaraman (2012).

With respect to higher office seeking, the results are not consistent with a positive incumbency advantage. There is no evidence that incumbents are more likely to run for higher office, perhaps reflecting the scarcity of and greater competition for higher office.

However, we found a clear incumbency effect on lower office seeking. Incumbents are less likely to run for lower office in the subsequent election than competitive challengers, which is also consistent with Table 04. Results show that challengers are between $5 \%$ and $8 \%$ more likely to run for a lower position than incumbents. This is reasonable since most lower positions are in local governments and it is very unlikely that a deputy would renounce a position in Congress to become mayor - except in a large city. Meanwhile, the status quo option for a loser is nothing.

In sum, we found a positive and significant incumbency advantage. That advantage affects the chances of reelection and influences future career paths. We

$$
\text { (2022) } 16(1) \quad \text { a } \quad \text { e0004-25/39 }
$$


presume that legislators can leverage public office resources to achieve future electoral goals, mostly to further their careers in Congress. However, we do not know which mechanisms are transforming these resources into additional votes. In the next section, we attempt to disentangle the direct impact of public office resources from the indirect impact of having access to more money for the reelection campaign.

\section{Campaign spending as a mechanism for the incumbency advantage}

Since we found clear evidence of a substantial incumbency advantage, our next step is to identify the mechanisms sustaining such advantage. We hypothesize that this effect is partially associated with the fact that some candidates are better able to raise campaign funds than others. To explore this hypothesis, we utilize data on campaign expenditures collected by The Brazilian Electoral Court since 2002. First, we estimate the incumbency effect on campaign funds using the same empirical strategy previously used for the election results. If an effect on campaign funds is confirmed in this first step, we will then attempt to decompose the direct incumbency effect on electoral outcomes and the indirect effect of larger campaign funds.

Figure 04 Panel A presents the results for the incumbency effect on the log of total campaign expenditures. Although we found a positive effect of about $20 \%$, such parameter is not significant for the local linear estimation and the quadratic estimation; however, it is significant at 5\% and considerably high (almost $40 \%$ ) for the cubic polynomial estimation. All in all, our results suggest a positive incumbency effect on campaign funds, but it is an imprecise estimate. When using our preferred polynomial strategy (local linear), the impact of incumbency on campaign resources is not significant at any reasonable level.

In the second step of the analysis, we proceed by estimating the direct and indirect effects of incumbency on electoral outcomes. We employ the same regression on electoral outcomes shown in Figure 02, but now we add campaign expenditures in $t+4$ as a control. Although this is an endogenous variable, the idea is to investigate whether the results in Figure 02 remain significant after controlling

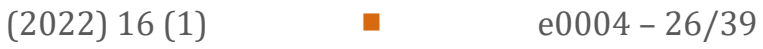


for campaign expenditures.

Figure 04 Panel B shows the results. Both analyses tell a similar story to that of Figure 02: even after controlling for campaign spending, incumbency is found to provide a substantial advantage in terms of reelection-seeking and winning. Incumbency effects on reelection, on the other hand, are only slightly reduced. As shown in Figure 02, incumbency effects on votes are not significant in any specification. These results suggest that incumbency advantage in Brazil is related to sources other than higher campaign spending. Exploring these other factors is beyond the scope of this paper, but we suggest that future studies examine patterns of pork barrel and budget amendments, name recognition, and media exposure.

Figure 04. Incumbency effect and campaign expenditures for federal deputies in Brazil for different polynomial specifications (1998 to 2018)

A. Incumbency effect on campaign expenditures

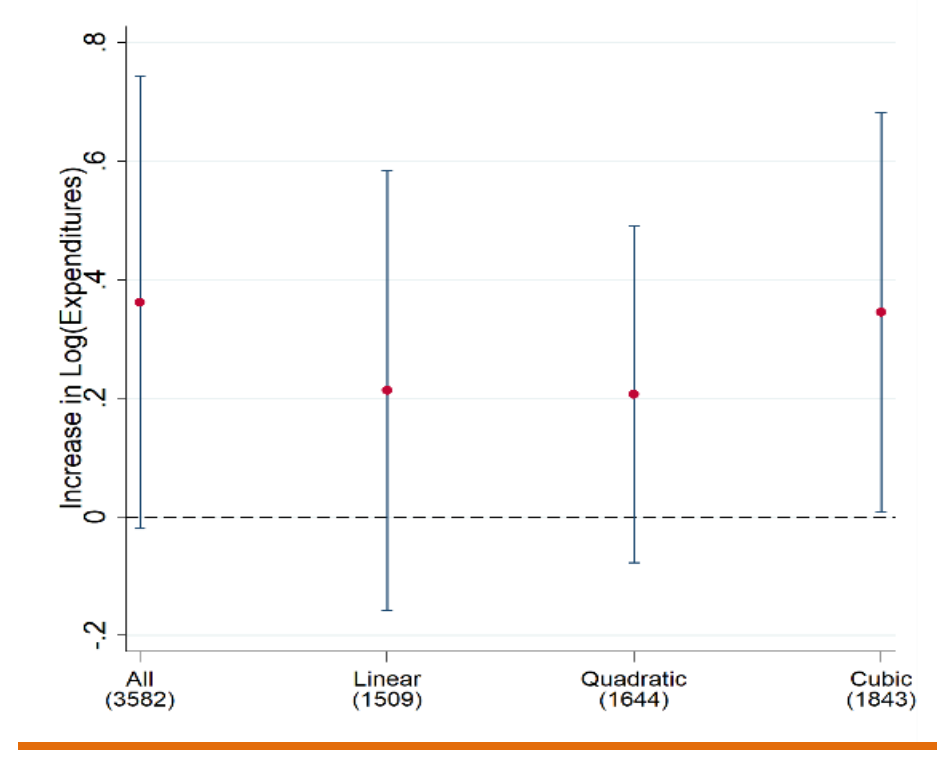

(continue) 
Figure 04. Incumbency effect and campaign expenditures for federal deputies in Brazil for different polynomial specifications (1998 to 2018) (continuation)

B. Incumbency effect on the likelihood of reelection controlling for campaign expenditures

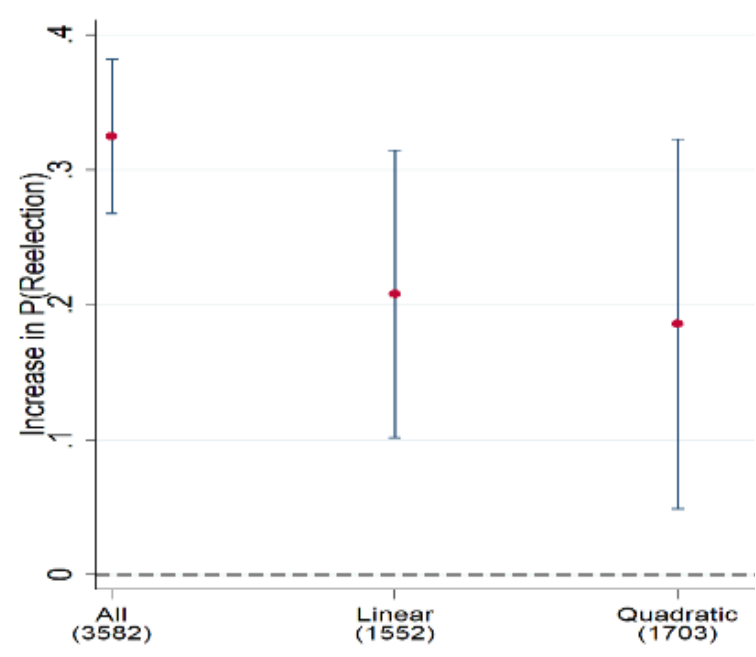

C. Incumbency effect on $\log$ (Votes) controlling for campaign expenditures

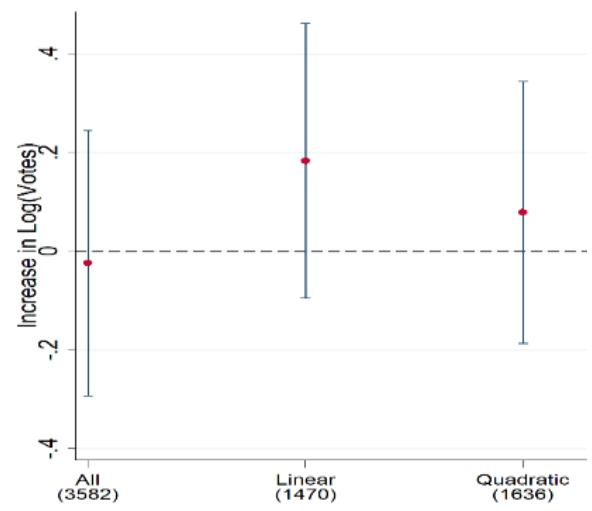

Polynomial Specification

Polvnomial Specification

Source: Elaborated by the authors based on CEPESP (2020).

Notes: 01. Binning estimator (red dots) and confidence intervals (black line) are calculated using robust standard errors and $95 \%$ confidence level. 02 . The number of observations in parenthesis is defined by optimal bandwidth following Imbens and Kalyanaraman (2012).

\section{Development, parties, institutions, and the incumbency advantage}

In a final step, we explore three popular arguments in the literature, leveraging Brazil's great diversity to conduct within-country tests of the correlation between incumbency effect and development, party strength, and electoral rules. These variables have been suggested in previous analyses as affecting the size and significance of the incumbency advantage, but most tests have been conducted in single-case studies without any variance.

Our general finding of a positive incumbency advantage in Brazil contradicts the hypothesis that the incumbency advantage should be negative in developing countries. Yet, since our result might be reflecting some of the country's particularities, we can further exploit our case by comparing the size of the incumbency advantage across cities and states, which vary in their levels of development. Specifically, we interact literacy with the treatment, 'Elected'. For this 
analysis, we calculated the average literacy rate of each candidate's electoral base. Specifically, we used the average municipal-level literacy rate, weighted by the proportion of votes for each candidate in the municipality. Although many candidates run in the same large districts, they generally concentrate their vote shares geographically. Consequently, within the same district, some candidates may receive votes in highly urban and developed regions, while others receive votes in less developed regions.

In addition to development, we examine two other hypotheses in the literature. More recent research has suggested that the incumbency advantage should be weaker where there are stronger parties (GOLDEN and PICCI, 2015; JACOBSON, 2015). While Brazil has been widely characterized as a weak party system, there are exceptions to this rule. Most notably, the Workers' Party is known for having many characteristics of an institutionalized party (AMARAL 2011; HUNTER, 2007; RIBEIRO, 2014; SAMUELS, 1999; SAMUELS and ZUCCO JR., 2018). It is the only Brazilian party with a large mass following, it has the largest official membership, and is known for enforcing discipline on its elected members. We thus test for an interaction between 'PT' - a dummy variable for the Workers' Party - and 'Elected'.

Lastly, scholars have suggested that intraparty competition reduces the incumbency advantage (ARIGA, 2015). While Brazil's electoral rules encourage intraparty competition in all Chamber of Deputy elections, the degree of competition should vary with district magnitude (CAREY and SHUGART, 1995). Brazil's electoral districts vary greatly in magnitude, from just 08 legislators in the smallest states to 70 in the district/state of São Paulo. Consequently, we test for an interaction between two dummies representing the extreme values of 'District Magnitude' and 'Elected'.

To be clear, these three tests for heterogeneity in the incumbency advantage do not identify causal effects of development, party strength, or district magnitude. They also may be confounded with other unobserved factors. Consequently, they should be treated as correlations and as suggestive evidence. Furthermore, while there is substantial within-country variance in Brazil, it does not 
capture the full range of development, party strength, or district magnitude observed globally ${ }^{19}$. In addition, while these state- and party-level analyses naturally create a multi-level model, our key variables of interest are at the group level, and we simply do not have enough groups for a more rigorous test of our hypotheses. It could also be that we are confounding our heterogeneity results with other variables. Although it is not possible to control for unobserved variables, we did run heterogeneity tests to control for some state-level variables (including fixed effects by state) and found very similar results ${ }^{20}$. For all these reasons, these tests should be considered suggestive. Even so, they are important since they offer a new perspective on the core hypotheses in the literature on incumbency effects, many of which have been developed without any variance in explanatory variables.

Figure 05 shows the results from these interactions for each of the variables discussed above: Literacy, PT, and District Magnitude. First, as shown in Panel A, there is a relationship between development and the incumbency advantage - but our results contrast with findings in the broader literature. According to our results, the incumbency advantage is largest in Brazil's least developed areas, and these differences are substantively and statistically significant at the $2 \%$ bandwidth. For an incumbent with an electoral base with a low literacy rate, her incumbency advantage is huge: she is $100 \%$ more likely to be reelected.

This finding casts doubt on the idea that voters in less developed areas are more critical of underperforming governments. One possible explanation, as we theorized above, is that incumbents are able to leverage the distributional benefits of public office and build support for subsequent elections. In more developed areas, voters place less value on government distribution, and distributive resources are less valuable (DESPOSATO, 2001). There are other potential mechanisms at work, including information, party strength, and, of course, other unobserved factors. The results from this within-country comparison, however, suggest that the conventional wisdom, at a minimum, needs closer examination.

\footnotetext{
${ }^{19}$ Indeed, the most important variance may be between district magnitude of one and seven, while we only observe district magnitude between eight and seventy.

${ }^{20} \mathrm{All}$ results from the heterogeneity tests adding covariates are available at the Harvard Dataverse repository (https://doi.org/10.7910/DVN/5GVHTE).
}

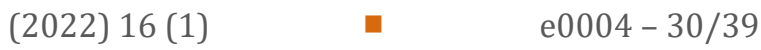


Panel B shows the impact of party strength on incumbency effects. As discussed above, previous work suggests that party strength is inversely related to the incumbency advantage (GOLDEN and PICCI, 2015; JACOBSON, 2015), and our results are consistent with that literature. For both votes and reelection, the incumbency effect for the Worker's Party is never significantly different from zero, which corroborates findings from Schiumerini (2018), but it is positive and significant for other parties for any bandwidth. This result supports Golden and Picci's (2015) hypotheses that incumbency effects are stifled by party organizations that control nominations and resources. Note, however, that there is not a significant difference between PT and non-PT parties in terms of the coefficients' magnitude.

Figure 05. Heterogeneity in the incumbency effect

Panel A. Incumbency effect by literacy rate

A1. Incumbency effect on the likelihood of reelection for low and high literacy rates

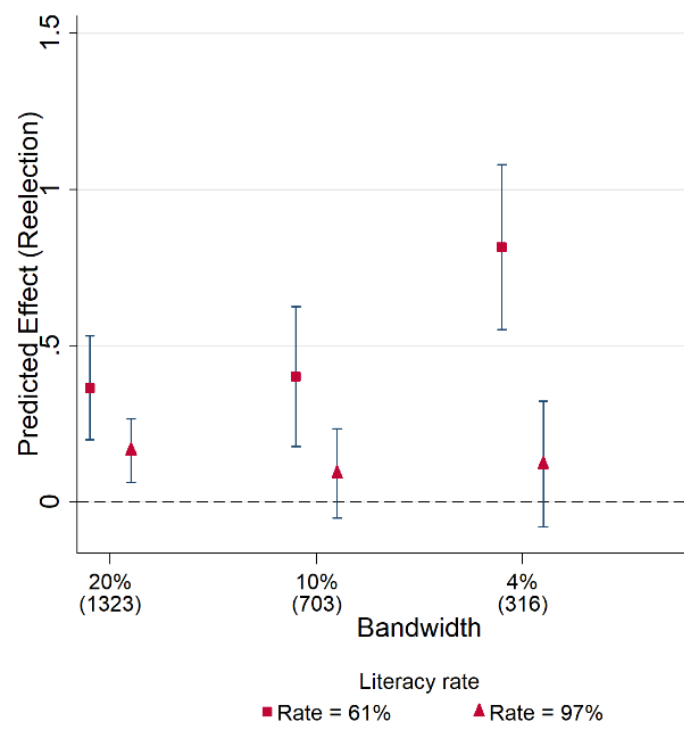

(continue)
A2. Incumbency effect on $\log$ (Votes) for low and high literacy rates

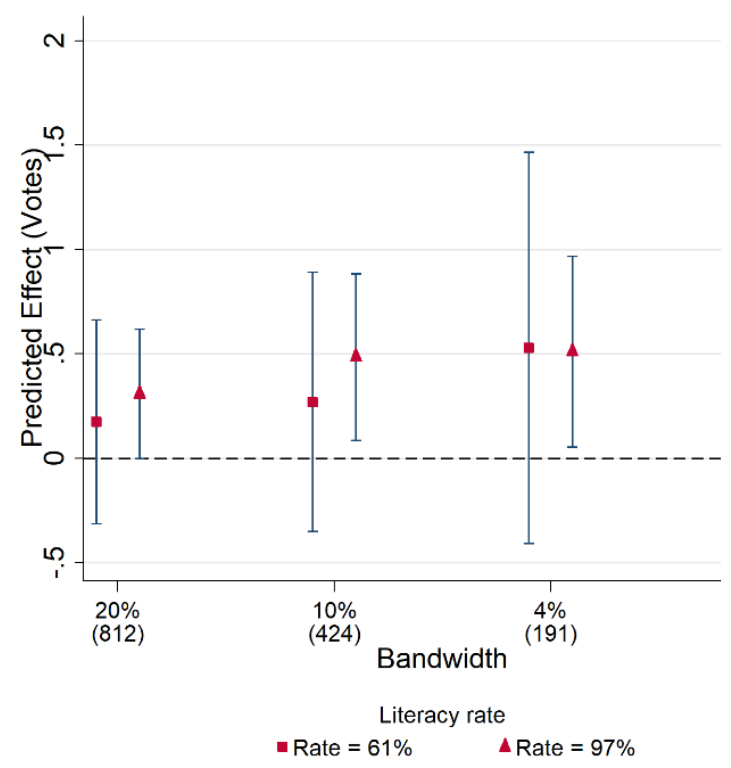

e0004 - 31/39 
Figure 05. Heterogeneity in the incumbency effect (continuation)

Panel B. Incumbency effect by party strength

B1. Incumbency effect on the likelihood of reelection for $\mathrm{PT}$ and other parties

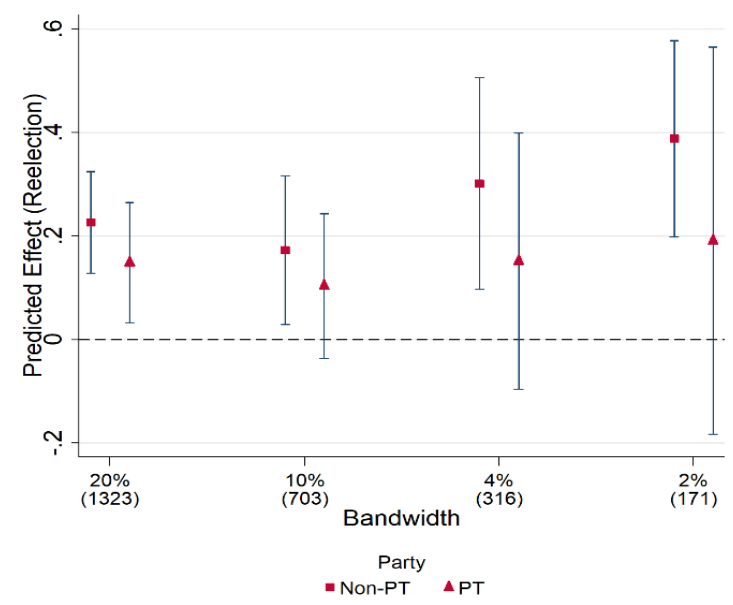

Panel C. Incumbency effect by district magnitude

C1. Incumbency effect on the likelihood of reelection for small and large district magnitudes

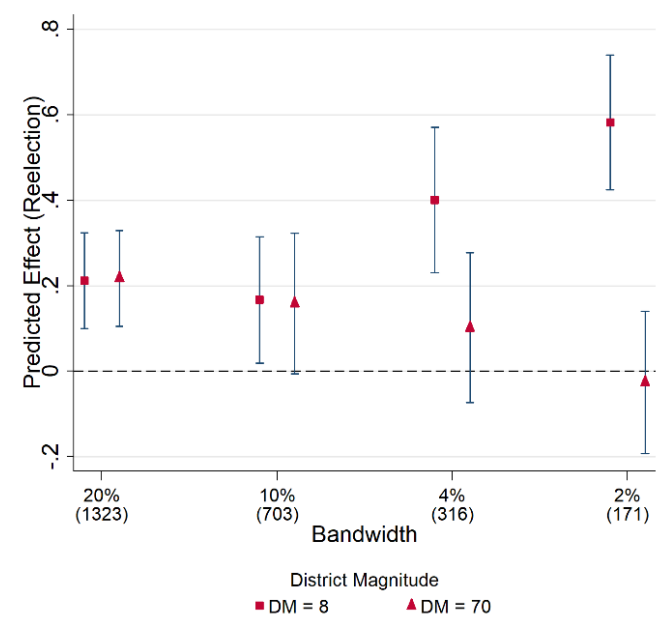

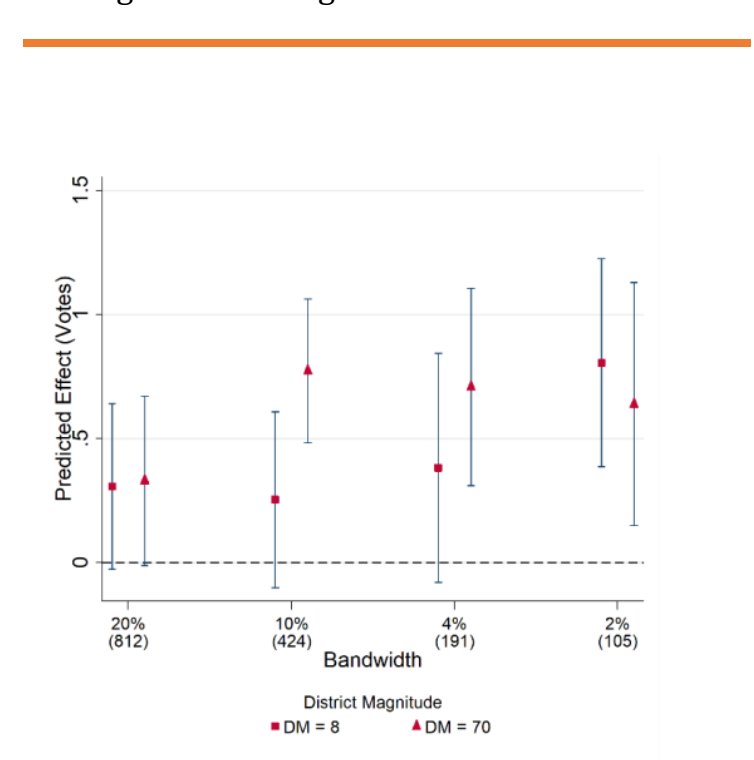

B2. Incumbency effect on $\log$ (Votes) for $\mathrm{PT}$ and other parties

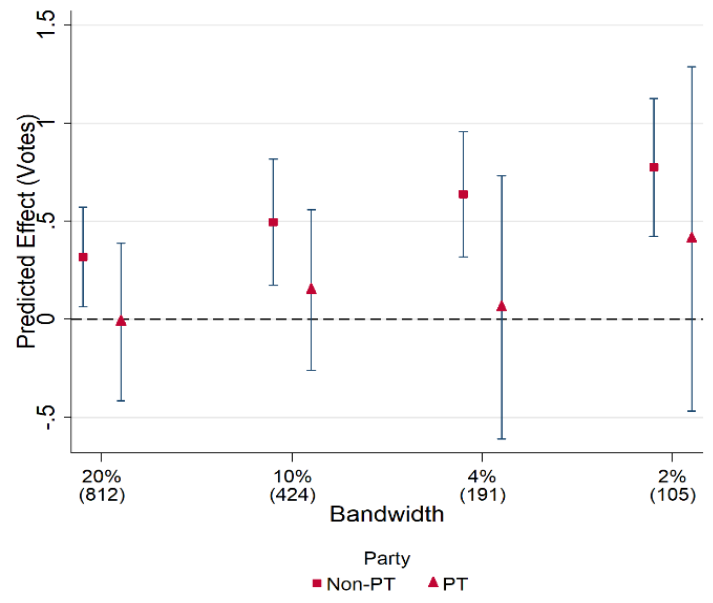

C2. Incumbency effect on $\log$ (Votes) for small and large district magnitudes

Source: Elaborated by the authors based on CEPESP (2020).

Notes: 01. Binning estimator (red dots) and confidence intervals (black line) are calculated using robust standard errors and $95 \%$ confidence level. 02. The number of observations in parenthesis is defined by optimal bandwidth following Imbens and Kalyanaraman (2012).

$$
\text { (2022) } 16(1) \quad \text { e0004-32/39 }
$$


Finally, previous work has also suggested that intraparty competition should reduce the incumbency advantage by providing voters with multiple candidates from their preferred parties (ARIGA, 2015). Although Brazil uses OLPR for all deputy elections, variation in district magnitude should correlate positively with intraparty competition and negatively with the incumbency advantage. Indeed, in panel $\mathrm{C}$, we find a negative relationship between district magnitude and the incumbency advantage. For reelection rates, incumbency has a substantial and positive effect in the smallest districts when we restrict the bandwidth for $4 \%$ or $2 \%$, while there is no impact of incumbency in São Paulo, Brazil's largest district at those bandwidths. For $20 \%$ or $10 \%$ bandwidths, the impact for the smallest districts $(m=8)$ or São Paulo $(m=70)$ are virtually the same and significant at $5 \%$ level.

\section{Conclusion}

A growing literature finds a negative incumbency advantage in the developing world, where incumbents are less likely to be elected in subsequent elections than their opponents. This finding seems counterintuitive, given the large literature on clientelism and the potential advantage that incumbents may enjoy given their privileged access to state resources. Previous scholars have speculated as to the origins of this disadvantage, relating it to voter frustration, to institutions, and to party organizations.

We contribute to this literature by examining the case of Brazil. Brazil fits the extant literature's profile for a negative incumbency advantage. This case also provides dramatic cross-district differences in human and economic development, party organizations, and district magnitude. This variation constitutes an opportunity for theory development, as it allows for a within-country test of the literature's main hypotheses. Finally, we offer a new approach for studying incumbency effects under OLPR that accounts for both inter- and intraparty electoral thresholds.

We found that Brazilian incumbents enjoy a strong, positive incumbency advantage that is robust to multiple samples and methods. Our analysis suggests 
that this advantage is partly explained by its impact on campaign spending, although most of the advantage appears to be due to other factors.

These results contrast with findings from research on Brazilian mayors (KLAŠNJA and TITIUNIK, 2017). Why is the incumbency advantage negative for mayors but positive for legislators? One possibility is that the incumbency advantage may be limited to legislative offices, where politicians do not bear as much direct responsibility for policy 'outcomes as their counterparts in the executive (ANSOLABEHERE and SNYDER, 2002). An alternative explanation, following Magalhães (2015), is that most previous work on mayoral incumbency in Brazil examines party incumbency, not individual incumbency. This may distort the measurement of the incumbency advantage, which is often seen as an individual, not as a partisan characteristic.

More broadly, we show that the incumbency advantage is largest among politicians from the least-developed areas. For incumbents with electoral bases in the least developed areas, the incumbency advantage was tremendous: holding office nearly quadrupled future vote share when compared to candidates that lost the previous election. Similarly, narrowly winning an election doubles the probability of a subsequent electoral victory.

These figures overwhelm the typical 4-8\% incumbency advantage observed in US elections and are consistent with what we know about politics in the developing world, where public goods of government are captured by elected officials and used as patronage and distributive goods. In these countries, incumbents usually have tremendous power over access to public goods and services, and they also often use government resources to support their careers and enrich themselves. On the other hand, in the most developed parts of Brazil, there is limited or no discernable incumbency advantage. We find similar results for district magnitude: the largest districts have the smallest advantages, while small states have much smaller advantages. Lastly, we find suggestive - but not significant - evidence that stronger parties have smaller incumbency advantages. These heterogeneity tests, although limited and not fully identified, suggest that the broader pattern of a negative incumbency advantage in developing

$$
\text { (2022) } 16 \text { (1) - } \quad \text { - e0004-34/39 }
$$


countries is likely confounded by other country-specific factors and is not in fact 'caused' by underdevelopment.

We suggest several avenues for future research. One would be to test a broader theory of incumbency effects cross-nationally, controlling for partisanship, electoral rules, legislative professionalism, and other predictors. For Brazil, however, we suggest an analysis of both state and city legislatures. Previous work has found that mayors have a negative advantage; resolving this contradiction with our findings will require examining city council elections. Also, the great diversity of Brazil's cities in terms of political systems, development, and other variables will provide leverage to help scholars build a general theory of how politicians use office to further their careers.

Revised by Karin Blikstad Submitted on July 20, 2020 Accepted on June 29, 2021

\section{References}

ADE, Florian; FREIER, Ronny, and ODENHDAHL, Christian (2014), Incumbency effects in government and opposition: evidence from Germany. European Journal of Political Economy. Vol. 36, Issue C, pp. 117-134.

ALMEIDA, Alberto C. (2006), Amnésia eleitoral: em quem você votou para deputado em 2002? E em 1998? In: Reforma política: lições da História recente. Edited by SOARES, Gláucio Ary Dillon and RENNÓ JR., Lucio Remuzat. Rio de Janeiro: Ed. FGV. pp. 34-46.

AMARAL, Oswaldo (2011), Ainda conectado: o PT e seus vínculos com a sociedade. Opinião Pública. Vol. 17, № 01, pp. 01-44.

AMES, Barry (2001), The deadlock of democracy in Brazil. Ann Arbor: University of Michigan Press. 352 pp..

AMES, Barry (1995a), Electoral rules, constituency pressures, and pork barrel: bases of voting in the Brazilian congress. The Journal of Politics. Vol. 57, № 02, pp. 324343.

AMES, Barry (1995b), Electoral strategy under open-list proportional representation. American Journal of Political Science. Vol. 39, № 02, pp. 406-433.

ANSOLABEHERE, Stephen and SNYDER Jr., James M. (2002), The incumbency advantage in U.S. elections: an analysis of State and Federal Offices, 1942-2000. Election Law Journal. Vol. 01, № 03, pp. 315-338.

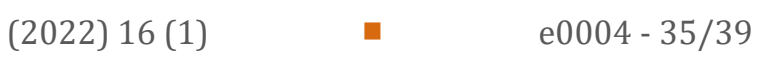


ARIGA, Kenichi (2015), Incumbency disadvantage under electoral rules with intraparty competition: evidence from Japan. Journal of Politics. Vol. 77, № 03, pp. 874-887.

ARIGA, Kenichi (2010), Entrenched incumbents, irresponsible parties? Comparative analysis of incumbency advantage across different electoral systems. Doctoral thesis. Philosophy in Political Science. University of Michigan.

ARIGA, Kenichi; HORIUCHI, Yusaku; MANSILLA, Roland, and UMEDA, Michio (2016), No sorting, no advantage: regression discontinuity estimates of incumbency advantage in Japan. Electoral Studies. Vol. 43, pp. 21-31.

BOAS, Taylor. C. and HIDALGO, F. Daniel (2011), Controlling the airwaves in Brazil. American Journal of Political Science. Vol. 55, № 04, pp. 869-885.

CAREY, John M. and SHUGART, Matthew S. (1995), Incentives to cultivate a personal vote: a rank ordering of electoral formulas. Electoral Studies. Vol. 14, № 04, pp. 417-439.

CARSON, Jamie L. and ROBERTS Jason M. (2013), Ambition, competition, and electoral reform. Ann Arbor: University of Michigan Press. 192 pp..

CATTANEO, Matteo D.; IDOBRO, Nicolás, and TITIUNIK, Rocio (2019), A practical introduction to regression discontinuity designs: an introduction. Cambridge: Cambridge University Press. 120 pp..

CATTANEO, Matteo D.; KEELE, Luke; TITIUNIK, Rocio, and VAZQUEZ-BARE, Gonzalo (2016), Interpreting regression discontinuity designs with multiple cutoffs. Journal of Politics. Vol. 78, № 04, pp. 1229-1248.

CEPESP (2020), TSE Data. Available at <http:cepespdata.io>. Accessed on July, 06, 2020.

COX, Gary W. and KATZ, Jonathan N. (2002), Elbridge Gerry's Salamander. Cambridge: Cambridge University Press. 248 pp..

COX, Gary W. and KATZ, Jonathan N. (1996), Why did the incumbency advantage in U.S. House elections grow? American Journal of Political Science. Vol. 40, № 02, pp. 478-497.

DESPOSATO, Scott William (2001), Institutional theories, social realities, and party politics in Brazil. Doctoral thesis. Philosophy in Political Science. University of California. 
DESPOSATO, Scott William and PETROCIK, John R. (2003), The variable incumbency advantage: new voters, redistricting, and the personal vote. American Journal of Political Science. Vol. 47, № 01, pp. 18-32.

EGGERS, Andrew. C. and SPIRLING, Arthur (2017), Incumbency effects and the strength of party preferences: evidence from multiparty elections in the United Kingdom. The Journal of Politics. Vol. 79, № 03, pp. 903-920.

FIORINA, Morris P. (1989), Congress: Keystone of the Washington Establishment. New Haven: Yale University Press. 192 pp..

FIVA, Jon H. and SMITH, Daniel M. (2018), Political dynasties and the incumbency advantage in party-centered environments. American Political Science Review. Vol. 112, № 03, pp. 706-712.

FOLKE, Olle (2014), Shades of brown and green: party effects in proportional election systems. Journal of the European Economic Association. Vol. 12, № 05, pp. 1361-1395.

FOWLER, Anthony (2018), A Bayesian explanation for the effects of incumbency. Electoral Studies. Vol. 53, pp. 66-78.

GOLDEN, Miriam and PICCI, Lucio (2015), Incumbency effects under proportional representation: Leaders and Backbenchers in the Postwar Italian Chamber of Deputies. Legislative Studies Quarterly. Vol. 40, № 04, pp. 509-538.

GROFMAN, Bernard (2005), Comparisons among electoral systems: distinguishing between localism and candidate-centered politics. Electoral Politics. Vol. 24, № 04, pp. 735-740.

GUARNIERI, Fernando (2011), A força dos partidos 'fracos'. Dados. Vol. 54, № 01. pp. 235-258.

HIDALGO, F. Daniel and OLIVEIRA, Renato Lima de (2016), Elite contestation and mass participation in Brazilian legislative elections, 1945-2014. In: New order and progress: development and democracy in Brazil. Edited by SCHNEIDER, Ben Ross. Oxford: Oxford University Press. pp. 241-267

HUNTER, Wendy A. (2007), The normalization of an anomaly. World Politics. Vol. 59, № 03, pp. 440-475.

IMBENS, Guido and KALYANARAMAN, Karthik (2012), Optimal bandwidth choice for the regression discontinuity estimator. The Review of Economic Studies. Vol. 79, № 03, pp. 933-959.

JACOBSON, Gary C. (2015), It is nothing personal: the decline of incumbency advantage in US house elections. Journal of Politics. Vol. 77, № 03, pp. 861-873.

$$
\text { (2022) } 16(1) \quad \text { a } \quad \text { e0004-37/39 }
$$


JACOBSON, Gary C. and KERNELL, Samuel (1981), Strategy and choice in Congressional Elections. New Haven: Yale University Press. 111 pp..

KECK, Margaret (1992), The Worker's Party and democratization in Brazil. New Haven: Yale University Press. 315 pp..

KLAŠNJA, Marko (2015), Corruption and the incumbency disadvantage: theory and evidence. The Journal of Politics. Vol. 77, № 04, pp. 928-942.

KLAŠNJA, Marko and TITIUNIK, Rocio (2017), The incumbency curse: weak parties, terms limits, and unfulfilled accountability. American Political Science Review. Vol. 101, № 01, pp. 129-148.

KOTAKORPI, Kaisa; POUTVAARA, Pana, and TERVIÖ, Marko (2017), Returns to office in national and local politics: a bootstrap method and evidence from Finland. The Journal of Law, Economics, and Organization. Vol. 33, № 03, pp. 413442.

LEE, Alexander (2016), Anti-incumbency, parties, and legislatures: theory and evidence from India. Department of Political Science. University of Rochester. Mimeo.

LEE, David S. (2008), Randomized experiments from non-random selection in U.S. House elections. Journal of Econometrics. Vol. 142, pp. 675-697.

LUCARDI, Adrian and ROSAS, Guillermo (2016), Is the incumbent curse the incumbent's fault? Strategic behavior and negative incumbency effects in young democracies. Electoral Studies. Vol. 44, pp. 66-75.

MACDONALD, Bobbie (2014), Estimating incumbency advantages in African politics: Regression discontinuity evidence from Zambian Parliamentary and local government elections. Working Paper no 14-151. London School of Economics and Political Science.

MAGALHÃES, Leandro (2015), Incumbency effects in a comparative perspective: evidence from Brazilian mayoral elections. Political Analysis. Vol. 23, № 01, pp. 113-126.

MAINWARING, Scott (1999), Rethinking party systems in the Third Wave of democratization: the case of Brazil. Stanford: Stanford University Press. 412 pp..

MAINWARING, Scott (1995), Brazil: weak parties, feckless democracy. In: Building democratic institutions: party systems in Latin America. Edited by MAINWARING, Scott and SCULLY, Timothy R. Scully. Stanford; Stanford University Press. Pp. 354-398.

$$
\text { (2022) } 16(1) \quad \text { a } \quad \text { e0004-38/39 }
$$


MAINWARING, Scott (1991), Politicians, parties, and electoral systems: Brazil in comparative perspective. Comparative Politics. Vol. 24, № 01, pp. 21-43.

MEIRELES, Fernando (2020), Carreiras Públicas na Câmara de Deputados: uma análise quase-experimental.” Dados. Vol. 62, № 04, pp. 01-38.

MICOZZI, Juan Pablo and LUCARDI, Adrián (2019), How valuable is a legislative seat? Incumbency effects in the Argentine Chamber of Deputies. Political Science Research and Methods. Vol. 09, № 02, pp. 414-429.

PEREIRA, Carlos and RENNO, Lúcio (2013), Should I stay or should I go. Journal of Politics in Latin America. Vol. 05, № 03, pp. 73-95.

REDMOND, Paul and REGAN, John (2015), Incumbency advantage in a proportional electoral system: a regression discontinuity analysis of Irish elections. European Journal of Political Economy. Vol. 38, Issue C, pp. 244-256.

RIBEIR0, Pedro Floriano (2014), An amphibian party? Organizational change and adaptation in the Brazilian Workers' Party, 1980-2012. Journal of Latin American Studies. Vol. 46, pp. 87-119.

ROH, Jungho (2017), The incumbency disadvantage in South Korean National Assembly elections: evidence from a regression discontinuity approach. Electoral Studies. Vol. 46, Issue C, pp. 112-122.

SAMUELS, David (2003), Ambition, federalism, and legislative politics. Cambridge: Cambridge University Press. 266 pp..

SAMUELS, David (1999), Incentives to cultivate a party vote in candidate-centric electoral systems. Comparative Political Studies. Vol. 32, № 04, pp. 487-518.

SAMUELS, David and ZUCCO JR., César (ed)(2018), Partisans, antipartisans, and nonpartisans: voting behavior in Brazil. Cambridge: Cambridge University Press. 279 pp..

SCHIUMERINI, Luis (2018), Incumbency effects and democratic accountability in the developing world. Comparative Democratization. Vol. 16, № 01, pp. 12-15.

SHUGART, Matthew S. (2008), Comparative electoral systems research. In: Comparative Electoral Systems. Edited by GALLAGHER, Michael. Oxford: Oxford University Press. pp. 25-55.

UPPAL, Yogesh (2009), The disadvantaged incumbents: estimating incumbency effects in Indian State Legislatures. Public Choice. Vol. 138, № 01, pp. 09-27. 